\title{
Improvement and Dynamic Analysis of an Electromechanical Valve (EMV) System and Determination of Working Limits at Different Valve Lifts
}

\author{
Nida BIRGUL ${ }^{* 1}$
}

Accepted : 15/06/2017 Published: 30/06/2017

DOI: 10.18100/ijamec.2017528890

\begin{abstract}
In four stroke internal combustion engines, the valves control the gas inlet and outlet events. Electromechanical valve (EMV) systems perform the required valve timing independently of the crankshaft position. With this feature, EMV systems have a great potential for increasing engine performance, ensuring optimum fuel consumption and minimizing emissions. The intent of this study was to improve an EMV system, which has $12 \mathrm{~V}$ supply potential, and to investigate dynamic performance at different lifting valve operations and then to determine the support limits of an internal combustion engine. At the end of the development of the EMV system, the transition time for $6 \mathrm{~mm}$ valve lift was measured as $3.9 \mathrm{~ms}$. Accordingly, it is evaluated that a four-stroke internal combustion engine can be supported up to $5128 \mathrm{rpm}$
\end{abstract}

Keywords: Electromechanical Valve, Variable, Mechatronics, Internal Combustion Engine, Camless Engine, Solenoid

\section{Introduction}

Conventional engine technology uses mechanically driven camshafts, to perform the opening and closing phase of intake and exhaust valves. The opening and closing profiles of such valves is strongly coupled to crankshaft position. Therefore, the valve train is not a flexible device and it is not possible to adjust or adapt in real time the valve features according to the engine conditions. Consequently definition, the standard valve system put a limit on the performance of internal combustion engines.

The intake system on an engine, typically consists of an air filter, a throttle, individual fuel injectors, intake manifold, intake ports, intake valves. During the induction process, pressure losses ocur as the mixture or as the air passes through of these components. For this reason, the pressure dropping of an intake manifold decreases the volumetric efficiency of an engine.

For the internal combustion engine with the aim of improving performance, reducing fuel consumption and exhaust emissions, the variable valve timing is one of the effective and essential means. Variable valve systems that operate mechanically have eliminated most of above mentioned limitations. VVT technology uses the camshafts to open or close the valves like conventional engines valve train. Furthermore, mechanically operating variable valve systems are unable to change all operating parameters of valves at the same time and at infinite intervals.

Variable valve timing and lifting can dramatically change an engine's performance characteristics that tork, power and specific fuel consumption. VVT is one of the effective and essential means for the internal combustion engine with the aim of improving performance [1], [3]-[6].

The development of an effective variable valve system strongly relies on innovative valve actuators. There are several valve devices that electromechanical valve (EMV) actuators,

${ }^{1}$ Baskent University, Kazan Vocational School, 06980, Ankara, TURKEY *Corresponding Author: Email: nbirgul@baskent.edu.tr electro-hydraulic[7]-[10], hydraulic, pneumatic[11], [12] and motor-driven systems[13], [14] have been proposed to implement variable valve timing (VVT).

The variable valve timing without camshaft is also called camless valvetrain or electromechanical valve (EMV) system. For this system, the camshaft mechanism is replaced by an electric or hydraulic or pneumatic system and the fully controls of the duration and valve stroke with possibly infinite variable valve timing is able to be achieved.

Electromechanical valve (EMS) systems are generally based on mechanism design [15]-[19], design influencing factors [20], [21], noise reduction [22], modeling and simulation [1], [3], [23][26], control and optimization [27]-[29] and engine applications [30]-[32].

Studies have shown that significant benefits in terms of fuel consumption, emissions, and torque production can be obtained through the adoption of Variable Valve Actuation (VVA) operations [33]-[39], in particular cylinder deactivation[40] and Variable Valve Timing (VVT) over all engine operating conditions.

The aim of this study was to improve an EMV system and to investigate dynamic performance at different lifting valve operations and then to determine the support limits of an internal combustion engine, and also to investigate the switchability capacity of the new EMV system in return to the opening and closing movement of a standard valve [41].

In this study, the previously produced system will be named as EMV1 and later developed system will be named as EMV2.

\section{Electromechanical Valve (EMV) System}

Electromechanical valve (EMV) systems are designed to operate the valves independently of the crankshaft. The system basically consists of an electronic control unit, two coils, two springs, a core and a valve. In Figure 1, the elements composing an electromechanical valve system are shown schematically. 


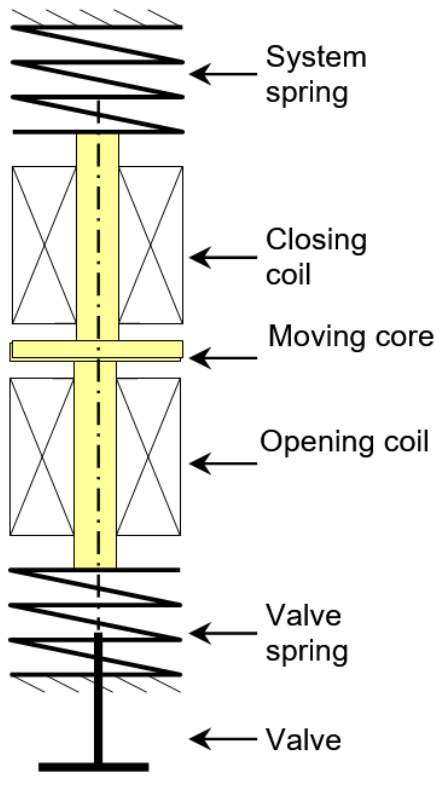

Figure 1. EMV system parts

The signals required for the control of the system are provided by the electronic control unit. The valve is opened and closed by transmitting the current from one of the coils and cutting off the current from the other one depending on the control signal sent by the electronic control unit (module). The electromagnetic force formed moves the core within the distance between two coils. The valve located at the end of the core fulfills the task of opening and closing by following the movement of the core. The system spring in the mechanism applies force in the direction of opening the valve and the valve spring applies force in the direction of closing the valve. When no signal is applied to the system, the moving core is kept in the middle position under the effect of the spring forces, and the valve is kept in the semi-open position.

\section{Experimental Setup}

For the purpose of determining the dynamic characteristics of the EMV system, the picture of the Experimental setup is presented in Figure 2. To create the experimental setup, the EMV system with $12 \mathrm{~V}$ operating voltage was connected to the cylinder head of a single-cylinder engine. The power electronic circuit was installed to control the system. The Pulse-Width Modulator (PWM) was produced to ensure the control of the EMV system by a computer. A computer interface program was created to provide an easy data entry to the system by the PWM. Thus, the desired PWM signal data can be easily transferred to the computer and the preferred control signals can be sent to the EMV system via the interface module and the PWM.

MOSFET integrators were used in driving solenoids that took on the opening and closing task in the EMV system. In order to reveal the dynamic working parameters of the system, it is needed to measure the coil current, control signals, and valve movements. For this purpose, hall sensors were used. Here, two hall sensors were used to measure each coil current and one hall sensor was used to sense the valve movement and the current and position information was obtained with these sensors.

ART USB5935 data logger and control module was used to collect and record the current, position and control information obtained from the sensors.

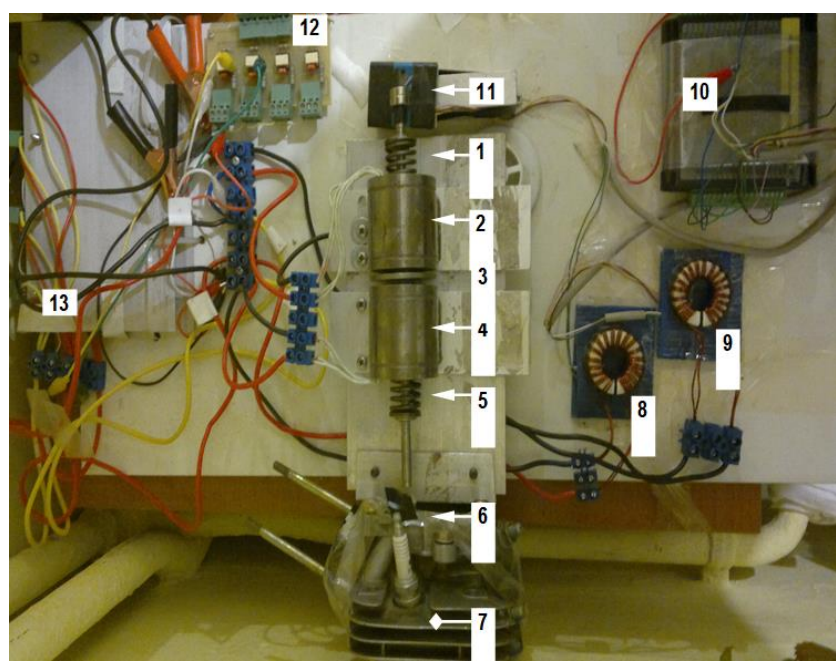

(1. System spring, 2. Closing solenoid, 3. Core, 4. Opening solenoid, 6. Valve spring, 7. Valve Joint, 8,9. Current sensors, 10. Data Logger, 11. Motion sensor (hall), 12. Mosfet driver circuit, 13. Mosfet heatsink)

Figure 2. EMV system

\section{Mathematical Model}

The EMV system consists of the combination of three main subsystems: electrical, magnetic, and mechanical. The movement occurs as a result of the interaction of these three components. Here, while the electrical subsystem determines the current dynamics passing through the coil, the mechanical subsystem is responsible for the moving core dynamic. The interaction of the electrical and mechanical parts forms the magnetic part. The movement is performed by the magnetic force that is generated by the coil current and directly affects the core. The block diagram of the EMV system is presented in Figure 3. From the magnitudes in the figure, $\mathrm{E}$ is the voltage applied to the solenoids $(\mathrm{V}), \mathrm{I}$ is the current (A) passing through the coils, $\mathrm{F}_{\mathrm{m}}$ is the electromagnetic force $(\mathrm{N}), \mathrm{x}$ and $\mathrm{v}$ are the valve position $(\mathrm{m})$ and valve speed $(\mathrm{m} / \mathrm{s})$, respectively.

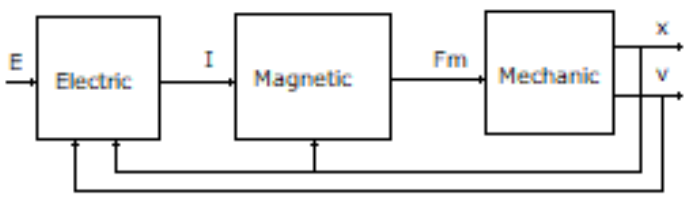

Figure 3. EMV system block diagram

\subsection{Electromagnetic Subsystem}

The electromagnetic correlation can be established with Kirchhoff's law and it is given in Equation 1. Here, e is the input voltage $(\mathrm{V}), \mathrm{r}$ is the coil resistance $(\mathrm{ohm}), \mathrm{N}$ is the number of turns and $\phi$ is the magnetic flux $\left(\mathrm{Wb} / \mathrm{m}^{2}\right)$.

$e(t)=\mathrm{ri}(t)+\frac{d(N \phi)}{d t}$

The electromagnetic force between the moving core and the constant pole can be calculated with equations 2 and 3 [19].

$$
\begin{aligned}
& F_{\mathrm{m}}=\frac{\mathrm{zB}_{h}{ }^{2} \mathrm{~A}}{2 \mu} \\
& F_{\mathrm{m}}=\frac{\mu \mathrm{A}(\mathrm{NI})^{2}}{2 \mathrm{z}\left(\mathrm{x}_{\mathrm{h}}-\mathrm{x}\right)^{2}}
\end{aligned}
$$


In the equations, $F_{m}$ stands for the electromagnetic force $(N), \mu$ for the air gap permeability $\left(4 \pi 10^{-7}\right)$, A for the effective crosssectional area $\left(\mathrm{m}^{2}\right), \mathrm{N}$ for the number of turns, I for the current (A) passing through the coil, $\mathrm{z}$ for the number of air gaps, $\mathrm{x}$ for the distance of the moving core to the full-open position, $\mathrm{x}_{\mathrm{h}}$ for the total movement distance $(\mathrm{m})$ and $\mathrm{B}_{\mathrm{h}}$ stands for the magnetic flux intensity $\left(\mathrm{Wb} / \mathrm{m}^{2}\right)$.

\subsection{Mechanical Subsystem}

The moving parts in electromechanical valve systems are a system consisting of the valve, core, and springs and this system is called the simple mass-spring system. The valve movement time is called the transition time from the open position to the closed position or from the closed position to the open position and it is approximately related to the natural frequency of the mass-spring system and can be calculated with Equation 4.

$$
\tau_{\mathrm{t}}=\pi \sqrt{\frac{m}{k}}
$$

Here, $\tau_{\mathrm{t}}$ stands for the transition time from the open position to the closed position or from the closed position to the open position, $\mathrm{m}$ for the total moving mass, and $\mathrm{k}$ for the spring constant. Equation 5 was used in the calculation of the moving mass. Here, the system spring and the valve spring used can be accepted to be of the same characteristics while considering the masses of the valve, core and springs.

Moving mass $=$ valve + core +

\section{[1/3 (valve spring + system spring)]}

In the EMV system, the spring force applied by the springs to the moving mass is given with Equation 6. Here, $\mathrm{k}$ stands for the spring constant $(\mathrm{N} / \mathrm{m})$. The electromagnetic force should be large enough to overcome the force applied by the springs. There are also in-cylinder pressure forces.

$$
F_{\text {yay }}=2 k\left(\frac{x_{h}}{2}-x\right)
$$

Equation 7 is used in the dynamic of the mechanical system.

$$
F_{m}=m \frac{d^{2} x(t)}{d t}+b \frac{d x(t)}{d t} \pm F_{y a y}+F_{b}+F_{s}
$$

Here, FyAY stands for the spring force $(N), F_{M}$ for the electromagnetic force $(\mathrm{N}), \mathrm{F}_{\mathrm{B}}$ for the friction force $(\mathrm{N})$, and $\mathrm{F}_{\mathrm{S}}$ stands for the cylinder pressure force $(\mathrm{N})$.

\section{Results and Evaluation}

In this section, the analyses of the first produced EMV1 system and the later developed EMV2 systems are given comparatively.

\subsection{Static Characteristics}

In order to determine the static characteristics of the EMV1 system, the electromagnetic force values that can be produced depending on the change in the static air gap used in the solenoid design are presented in Figure 4. According to this, it was evaluated that the electromagnetic force values to be obtained at $10 \mathrm{~A}$ current value had a capacity to overcome the original valve spring force used in the design and it would be possible to work with large spring forces at higher currents.

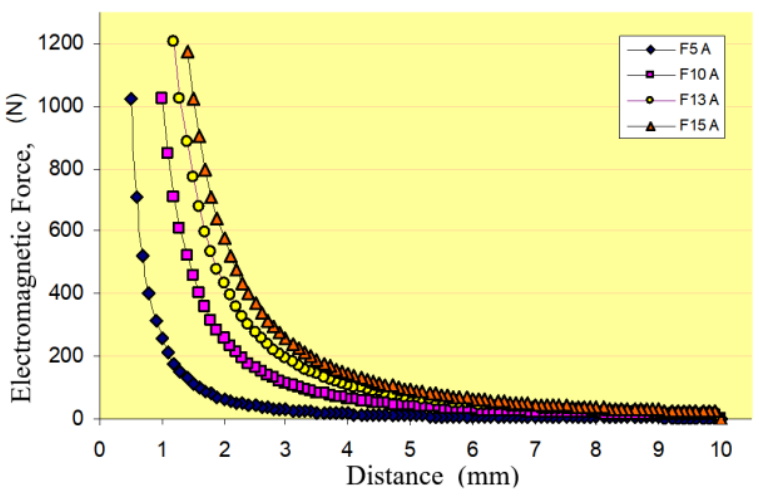

Figure 4. The change of the force to be produced depending on the change in static air gap

According to this, the newly designed solenoid was produced $2 \mathrm{~mm}$ narrower and $6 \mathrm{~mm}$ shorter, and no change was made in the number of turns.

The force-distance change graph obtained within the scope of increasing the attraction force and reducing the moving mass following the production of the EMV2 is given in Figure 5. The EMV2 graph is presented together with the EMV1 graph to make a sufficient comparison.

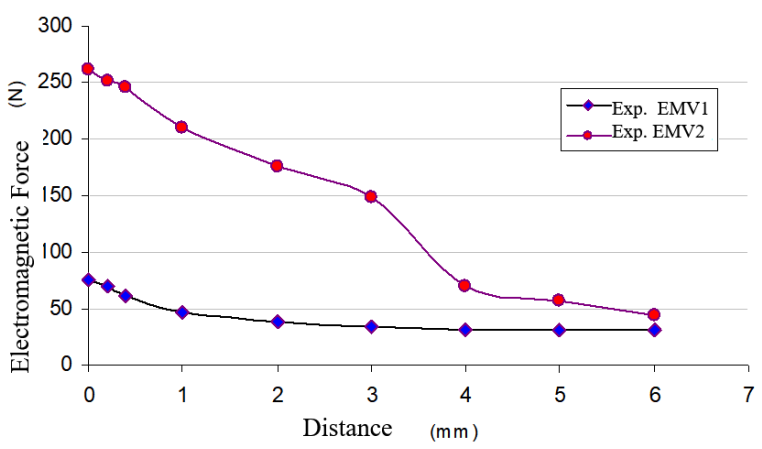

Figure 5. Measured Force - Distance change; I=10 A for EMV1, $\mathrm{I}=13,33 \mathrm{~A}$ for EMV2

After the improvement of the winding technique, the resistance of the coil produced was obtained to be $0.9 \mathrm{ohm}$. A decrease by $25 \%$ was provided by comparing this case to $1.2 \mathrm{ohm}$ resistance of the EMV1. Thus, the current drawn under $12 \mathrm{~V}$ voltage increased from the value of $10 \mathrm{~A}$ to the value of $13.33 \mathrm{~A}$ with an increase by $33.33 \%$ and more force production was ensured. According to this, the maximum force obtained from the solenoid of the newly designed and produced EMV2 was measured to be $260.85 \mathrm{~N}$. Upon comparing this value with the $76 \mathrm{~N}$ force, the maximum force value of the EMV1, it was observed that an increase was provided at the rate of 3,30 on average; upon being compared with the potential rate of improvement 3.28 times on average which was determined in the evaluation of the EMV1 system, it was observed that the targeted value was come up with the increase in the current provided in the coil current, and as a result, it was observed that the evaluations of the production and estimation of the design study were a quite successful study and evaluations. The comparison of the EMV2 system with the EMV1 and with other studies is given in Table I. In the EMV2 force - distance change graph, it is evaluated that the decrease of the force from $4 \mathrm{~mm}$ distance arises from the design, and a 2-2,5 $\mathrm{mm}$ distance is not used enough particularly in the beginning part and the values in the part following this part can be further increased in the case that the improvement study is maintained. 
Table I. The comparison of the EMV2 coil

\begin{tabular}{|c|c|c|c|}
\hline Operation & $\begin{array}{c}\text { Voltage } \\
(\mathrm{V})\end{array}$ & $\begin{array}{c}\text { Current } \\
(\mathrm{A})\end{array}$ & Force (N) \\
\hline EMV1 & 12 & 10 & 76 \\
\hline EMV2 & 12 & 13,33 & 260,9 \\
\hline$[31]$ & 42 & 7,5 & 69,6 \\
\hline$[23]$ & 42 & 15 & 600 \\
\hline$[21]$ & 180 & 5 & 1300 \\
\hline
\end{tabular}

\subsection{Dynamics of The EMV1 and EMV2 Systems}

Performance measurements were performed in the $2-7 \mathrm{~mm}$ valve operation range to determine the dynamic characteristics of the EMV system. To perform the measurements, on the one hand, the necessary control signals were sent to the pulse-width modulation (PWM) unit via computer, on the other hand, the data obtained from the sensors were recorded with the data logger system. A screen shot of these data is given in Figure 6 and the signal graphs obtained from the digital data records and used in the evaluations are given in Figure 7. According to this, if the obtained signals are counted from the top to the bottom, they will be the opening coil current, closing coil current, valve position, coil opening PWM signal and coil closing PWM signal, respectively.

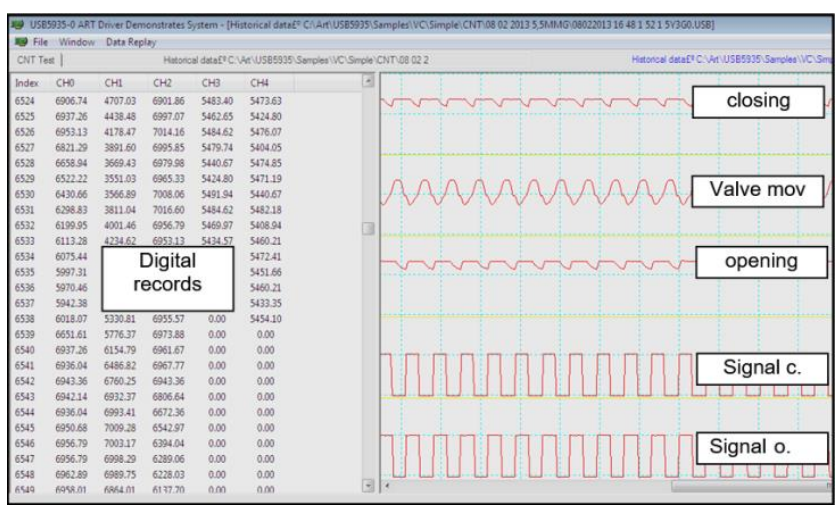

Figure 6. The screen shot of the data logger system

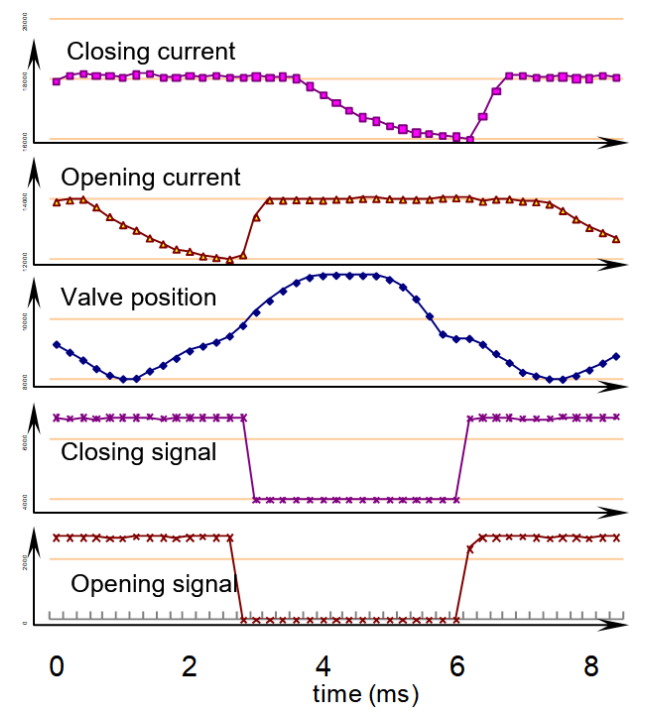

Figure 7. Experimental results of the dynamic characteristics

To determine the dynamic working limits, tests were performed in the valve operating ranges of $6 \mathrm{~mm}, 7.5 \mathrm{~mm}$, and $8 \mathrm{~mm}$ for EMV2. In Figure 8, the operating performances of the EMV1 and EMV2 systems in various operating ranges are presented. According to this, it was measured to be $5 \mathrm{~ms}$ and $9.5 \mathrm{~ms}$, respectively, for the operating ranges of $2 \mathrm{~mm}$ and $7 \mathrm{~mm}$ in the EMV1 system. The half-period times of $3.9 \mathrm{~ms}, 4.3 \mathrm{~ms}$, and 4.4 $\mathrm{ms}$, respectively, were obtained in the operating ranges of $6 \mathrm{~mm}$, $7.5 \mathrm{~mm}$ and $8 \mathrm{~mm}$ in the EMV2 system. Upon comparing these values with the EMV1 values, it is observed that the decrease in time at the rate of $54 \%, 57 \%$ and $58 \%$ is provided, respectively. The graphical solution of the improvement potentials of both systems is presented in Figure 9. It is observed that the increment of the spring coefficients used is needed for lower operating times. The comparison of the EMV1, EMV2 systems and certain magnitudes given in other sources is presented in Table II.

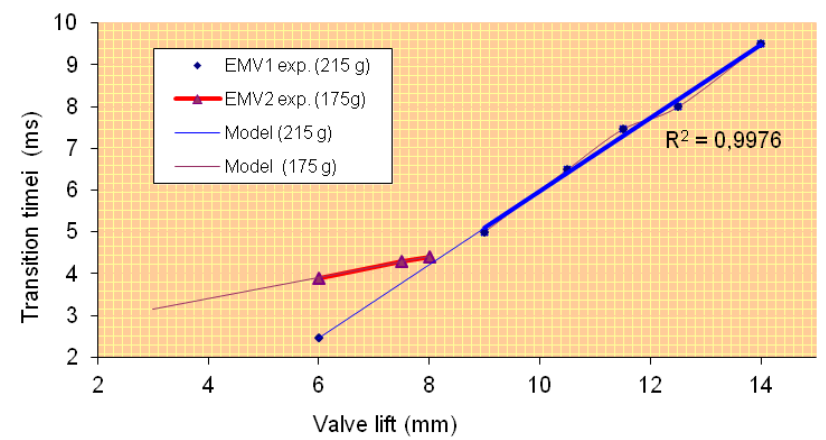

Figure 8. Dynamic performances of EMV1 $(\mathrm{K}=10 \mathrm{~N} / \mathrm{mm})$ and EMV2 $(\mathrm{K}=20 \mathrm{~N} / \mathrm{mm})$

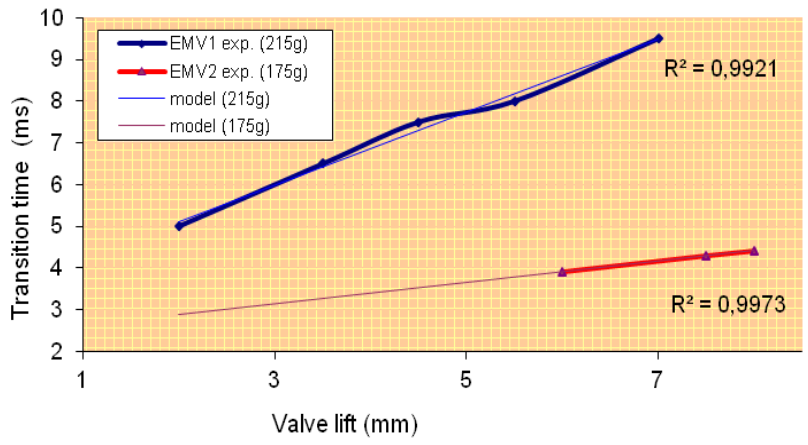

Figure 9. The comparison of the dynamic performances of the $\operatorname{EMV} 1(\mathrm{~K}=10 \mathrm{~N} / \mathrm{mm})$, and EMV2 $(\mathrm{K}=20 \mathrm{~N} / \mathrm{mm})$

Table II. The EMV2 system and certain magnitudes given in other sources

\begin{tabular}{|c|c|c|c|c|c|c|c|}
\hline $\begin{array}{c}\text { Operation } \\
\text { (Design) }\end{array}$ & EMV1 & EMV2 & EMV2 & {$[15]$} & {$[17]$} & {$[25]$} & {$[32]$} \\
\hline $\begin{array}{c}\text { Half- } \\
\text { opening } \\
\text { time (ms) }\end{array}$ & 8 & 3.9 & 4.4 & 3.42 & 3.33 & 4 & 9.5 \\
\hline $\begin{array}{c}\text { Movement } \\
\text { distance } \\
\text { (mm) }\end{array}$ & 5.5 & 6 & 8 & 8 & 8 & 8 & 4.5 \\
\hline $\begin{array}{c}\text { Voltage } \\
\text { (V) }\end{array}$ & 12 & 12 & 12 & 180 & 42 & 100 & 33 \\
\hline $\begin{array}{c}\text { Current } \\
\text { (A) }\end{array}$ & 10 & 13.3 & 13.3 & 5 & 15 & - & 10 \\
\hline
\end{tabular}

The engine parameters of which values are given in Table III are taken into account to demonstrate the realistic engine support status of the EMV2 system.

According to this, the change in the EMV2 opening or closing time required for the duration of the valve's remaining open was calculated according to the engine speed. According to this, in the case of applying this system studied to the engine, it was evaluated that it could support an internal combustion four-stroke engine at the speeds specified in Table IV for $6 \mathrm{~mm}, 6.5 \mathrm{~mm}, 7.5$ $\mathrm{mm}$ and $\quad 8 \mathrm{~mm}$ valve operating ranges. 
Table III. Characteristics of the internal combustion four-stroke engine

\begin{tabular}{|c|c|}
\hline Brand & Briggs and Stratton-Vanguard \\
\hline Number of cylinders & 1 \\
\hline Piston stroke & $50 \mathrm{~mm}$ \\
\hline Diameter of the cylinder & $68 \mathrm{~mm}$ \\
\hline Stroke volume & $182 \mathrm{~cm}^{3}$ \\
\hline Maximum speed & $36001 / \mathrm{min}$ \\
\hline Intake Opening Angel & $16^{\circ} \mathrm{CA} \mathrm{BTC}$ \\
\hline Intake Closing Angel & $44^{\circ} \mathrm{CA} \mathrm{ABC}$ \\
\hline Exhaust Opening Angel & $45^{\circ} \mathrm{CA} \mathrm{BBC}$ \\
\hline Exhaust Closing Angel & $15^{\circ} \mathrm{CA} \mathrm{ATC}$ \\
\hline Valve lift & $6 \mathrm{~mm}$ \\
\hline
\end{tabular}

Table IV. The engine support limits of the EMV2 system

\begin{tabular}{|c|c|c|c|c|c|}
\hline $\begin{array}{c}\text { Operating range } \\
(\mathrm{mm})\end{array}$ & 4.5 & 5.5 & 6 & 7 & 8 \\
\hline $\begin{array}{c}\text { Engine speed } \\
(1 / \mathrm{min})\end{array}$ & 5714 & 5263 & 5128 & 4761 & 4545 \\
\hline
\end{tabular}

To demonstrate the superiorities of the EMV2 system to the standard valve system, its dynamic performances at various circuits are graphically presented in Figure 10. According to this, the EMV2 system can operate up to the engine speed of 5128 $1 / \mathrm{min}$ at $6 \mathrm{~mm}$ valve lift. In the standard valve system, the opening and closing of the valves are not affected by the circuit change and display the operation associated with the crankshaft at each revolution. On the other hand, the opening time of the valve increases as the engine speed decreases in the EMV2 system. Upon comparing the valve opening time of the EMV2 system even at $51281 / \mathrm{min}$ speed with the standard valve graph, it is observed that the valve reaches the fully open position earlier and therefore, it has more opening time.

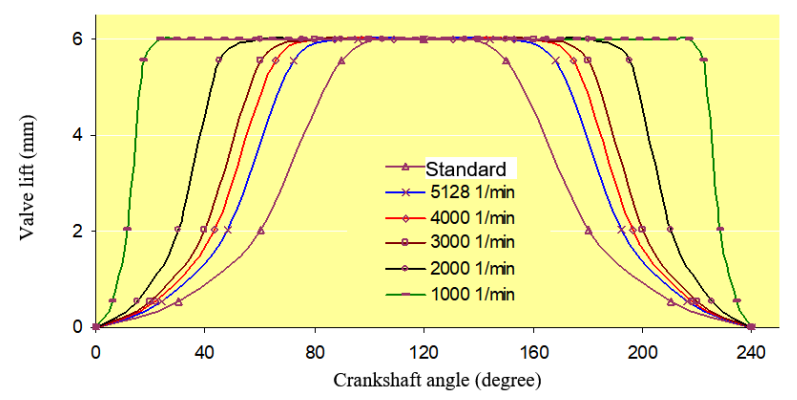

Figure 10. Dynamic performances of the standard valve system and the EMV2 system at various revolutions

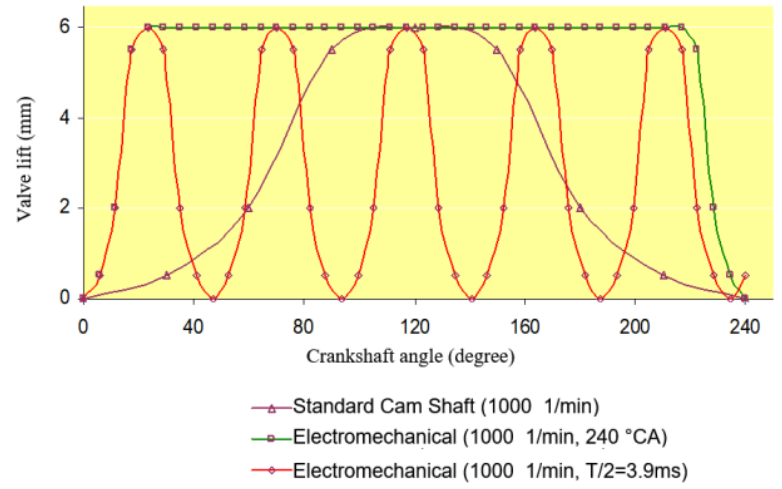

Figure 11. The switchability capacity of the EMV2 system in return to the opening and closing movement of a standard valve

The switchability capacity of the EMV2 system in the opening and closing movement of a standard valve is given in Figure 11.

At the time when the opening and closing movement of a standard valve system takes place, the EMV2 system has multiple switchability capacities. According to this, at 1000 1/min engine speed, within the time of an opening and closing of a standard valve, the EMV2 system can be switched five times in a row.

\section{Conclusion}

As a result of the determinations and evaluations on the improvement of the EMV1 system, the EMV2 system was designed and manufactured. According to this, the limits of supporting an internal combustion engine were determined. Furthermore, the dynamic performance at various revolutions and the fixed engine speed switchability capacities were compared according to the standard valve system.

It has been evaluated that further studies can be maintained on the improvement of the EMV systems which are compatible with the present automotive systems, can support internal combustion engines under any operating condition and have a low energy consumption, that the EMV2 system can be improved with strong magnets and can be turned into a Hybrid EMV system, and that its effects on the engine performance, exhaust emissions, and fuel consumption can be investigated.

\section{References}

[1] Gaeta, di A., Glielmo, L., Giglio, V. and Police, G., "Modeling of an electromechanical engine valve actuator based on a hybrid analytical-FEM approach", IEE/ASME Transactions on Mechatronics, 13 (6): 625-637 (2008).

[2] Birgül, N. "Design and development of an electromechanical valve system which will be used in internal combustion engines", Ph.D. Thesis, Karabuk University, Institute of Science (2014)

[3] Nagaya, K., Kobayashi, H. And Koike, K., "Valve timing and valve lift control mechanism for engines", Mechatronics, 16: 121-129 (2006).

[4] Çınar, C., Sekmen, Y., Akbaş, A. ve Erduranll, P., "Buji ile ateşlemeli motorlarda emme supabı kalkma miktarının performansa etkileri üzerine bir araştırma”, Pamukkale University Journal of Engineering Sciences, 10 (2): 179-184 (2004).

[5] Atzler, F., "On the future of the piston engine with internal combustion an overview", Marie Curie Fellowship Conference, Profactor GmbH, Steyr, Austria (2001).

[6] Shiao, Y. and Dat, L. V., "Efficiency improvement for an unthrottled SI engine at part load", International Jurnal Of Automotive Technology, 13 (6): 885-893 (2012).

[7] Wong, P.K., Tam, L. M. and Li, K., "Modeling and simulation of a dual-mode electrtrohydraulic fully variable valve train for fourstroke engines", International Journal of Automative Technology, 9 (5): 509-521 (2008).

[8] Heinzen, A. , Giella, P. and Sun, Z., "Iterative learning control of a fully flexible valve actuation system for non-throttled engine load control", Control Engineering Practice, 19 (12): 1490-1505 (2011).

[9] Gray, J., Krstic, M. and Chaturvedi, N, "Parameter identification for electrohydraulic valvetrain systems", Journal of Dynamic Systems, Measurement, and Control, 133 (064502): 1-8 (2011).

[10] Pournazri, M., Khajepour, A. and Fazeli, A., "An efficient lift control technique in electrohydraulic camless valvetrain using variable speed hydraulic pump", Society of Automotive Engineers (SAE), 2011-01-0940 (2011).

[11] Trajkovic, S., Milosavljevic, A., Tunestål, P. and Johansson, B., "FPGA controlled pneumatic variable valve actuation" Society of Automotive Engineers (SAE), 2006-01-0041 (2006).

[12] Trajkovic, S., Tunestål, P. and Johansson, B., "Introductory study of variable valve actuation for pneumatic hybridization", Society of 
Automotive Engineers (SAE), 2007-01-0288 (2007).

[13] Parlikar, T. A., Chang, W. S., Qiu, Y. H., Seeman, M. D., Perreault, D. J., Kassakian, Fellow, J. G., and Keim, T. A., "Design and experimental implementation of an electromagnetic engine valve drive", IEEE/ASME Transactions On Mechatronics, 10 (5): 482 494 (2005)

[14] Qiu, Y., Perreault, D. J., Kassakian, J. G. and Keim, T. A., "A custom-designed limited-angle actuator for an electromechanical engine valve drive. Part I: Conceptual design", Proceedings of the 5th IET International Conference on Power Electronics, Machines and Drives (PEMD), Brighton, UK (2010).

[15] Shiao, Y. and Pan, W., "Design of a 3-stage voltage controller for EMV actuation in SI engines", 2011 11th International Conferance On Control, Automation And Systems, Gyeonggi-do, Korea, (2011).

[16] Park, S., Kim, D. and Jaisuk, B., "A study on the design of electromagnetic valve actuator for VVT engine", KSME International Journal, 17 (3): 357-369 (2003).

[17] Jieng-Jang, L., Yee-Pien, Y. and Jia-Hong, X., "Electromechanical valve actuator with hybrid MMF for camless engine", Proceedings of the 17th World Congress The International Federation of Automatic Control, Seoul, Korea, 10688-10703 (2008).

[18] Kim, J. and Lieu, D. K., "Designs for a new, quick-response, latching electromagnetic valve", International Conference on Electric Machines and Drives, San Antonio, TX, United States, 1773-1779 (2005).

[19] Wong, P. K. and Mok, K. W., "Design and modeling of a novel electromechanical fully variable valve system", Society of Automotive Engineers (SAE), 2008-01-1733 (2008).

[20] Kamış, Z. ve Yüksel, İ., “ An investigation of effect of applied electrical voltage on system dynamic behaviour and energy consuption of an electromechanical valve actuator", G.U. Journal of Science, 17 (3): 161-177 (2004).

[21] Kim, J. and Lieu, D. K., "A new electromagnetic engine valve actuator with less energy consumption for variable valve timing", Journal of Mechanical Science and Technology, 21: 602-606 (2007).

[22] Peterson, K.S. And Stefanopouluo, A.G., "Extremum seking control for soft landing of an electromechanical valve actuator", Automatica, 40: 1063-1069 (2004).

[23] Eyabi, P., "Nonlinear estimation: An experimental approach", IEEE ISIE 2006 Montreal, Quebec, Canada, 102-108 (2006).

[24] Wang, Y., Megli, T., Haghgooie, M., Peterson, K. S. and Stefanopouluo, A. G. , "Modeling and control of electromechanical valve actuator", Society of Automotive Engineers (SAE), 2002-011106 (2002).

[25] Lua, C. A., Toledo, B. C., Benedetto, M. D. and Gennaro, S. D., "Output feedback regulation of electromagnetic valves for camless engines", Proceedings of the European Control Conference, Kos, Greece, 1-26 (2007).

[26] Miller, J., "Simulation of a novel electromechanical engine valve drive to quantify performance gains in fuel consumption", Master of Science Thesis, Massachusetts Institue of Technology, 14-27 (2011).

[27] Nam, K., "Development of a camless engine valve actuator system for robust engine valve timing control", Int. J. Vehicle Systems Modelling and Testing, 7 (4): 372-389 (2012).

[28] Mercorelli, P., "An adaptive two-stage observer in the control of a new electromagnetic valve actuator for camless internal combustion engines", New Trends and Developments in Automotive System Engineering, InTech, Rijeka Croatia, 343-368 (2011).

[29] Dat, L. V. and Shiao, Y., "Optimization intake valve timing in camless engine with electromagnetic valvetrain", Journal of Engineering Technology and Education The 2012 International
Conference on Green Technology And Sustainable Development, Hochiminh City, Vietnam, 368-373 (2012).

[30] Doğan, O. ve Özdalyan, B., "Effect of a semi electro-mechanical engine valve on performance and emissions in a single cylinder spark ignited engine", Journal of Zhejiang University-SCIENCE A (Applied Physics \& Engineering) 11 (2): 106-114 (2010).

[31] Sağıroğlu, S, ve Salman, M. S., "Buji ile ateşlemeli bir motorda elektromanyetik kumandalı supap mekanizması tasarımı, imalatı ve egzoz emisyonlarına etkisinin araştırılması", Teknoloji, 10 (2): 113 122 (2007).

[32] Doğan, O., "İçten yanmalı bir motorda elektro-mekanik supap uygulaması”, Bilim Uzmanlığı Tezi, Zonguldak Karaelmas Üniversitesi, Fen Bilimleri Enstitüsü, 25-70 (2006).

[33] Birgül, N. ve Sekmen, P., "Investigatıon of the dynamic performance of an electromechanical valve (EMV) system at different lifting operations and determination of the support limits of an internal combustion engine", Journal of The Faculty of Engineering and Architecture of Gazi University, 28 (3): 607-616 (2013).

[34] Gün, F., "Değişken supap zamanlamasının motor performansına etkilerinin deneysel incelenmesi”, Yüksek Lisans Tezi, Gazi Üniversitesi, Fen Bilimleri Enstitüsü, Ankara, 18-26 (2006).

[35] Parvate, P. G., "Solenoid operated variable valve timing for internal combustion engines", Master of Sciences Thesis, Concordia University, Montreal, Cuebec, Canada, 24-66 (2005).

[36] Akbaş, A., Çınar, C. ve Sekmen, Y., "Buji ile ateşlemeli motorlarda değişken supap zamanlamasının performansa etkileri üzerine bir araştırma", Pamukkale Üniversitesi, Mühendislik Bilimleri Dergisi, 7 (1): 35-38 (2001).

[37] Hara, S., Suga, S., Watanabe, S. and Nakamura, M., "Variable valve actuation systems for environmentally friendly engines", Hitachi Review, 58 (7): 319-324 (2009).

[38] Richter, H., Schwarzenthal, D. and Spiegel, L., "Variable valve actuation key technology for high specific power output and low exhaust emissions", International Conference Spark Ignition Engine: The CO2 Challenge, Venezia, 90-95 (2002).

[39] Carden, P., "Calculation of friction in high performance engines", Software European User Conference, Prague, Czech Republic, 1-47 (2010).

[40] Wilcutts, M., Switkes, J., Shost, M. and Tripathi, A., "Design and Benefits of Dynamic Skip Fire Strategies for Cylinder Deactivated Engines," SAE Int. J. Engines 6(1):2013, doi:10.4271/2013-010359.

[41] Birgul, N., "Improvement Of An Electromechanical Valve (EMV) System, Dynamic Analysis And Determination Of Working Limits At Different Liftings", 5th International Conference on Advanced Technology \& Sciences (ICAT'17), Istanbul, Turkey, 05.09-12 (2017).

Abbreviations

rpm revolutions per minute

CA Crankshaft Angle

ABC After Bellow Center crank position

ATC After Top Center

BBC Before Bellow Center

BTC Before Top Center 